\title{
ANALISIS TINGKAT KESEHATAN BANK MANDIRI MENGGUNAKAN RASIO CAMEL(PERIODE 2013 - 2016)
}

\author{
Fitria Rahma Pane, Riandani Rezki Prana, Zuhri \\ Alumni Sekolah Tinggi Ilmu Manajemen Sukma \\ Program studi Manajemen, Sekolah Tinggi Ilmu Manajemen \\ riandanirezki@gmail.com, zuhri6302@gmail.com
}

\begin{abstract}
Tujuan dari penelitian ini adalah penulis ingin mengetahui kondisi tingkat kesehatan keuangan pada Bank Mandiri, dengan menggunakan metode CAMEL yang terdiri dari Capital, Asset Quaity, Manajement, Earning, Liquidity pada periode tahun 2013-2016. Jenis penelitian ini adalah penelitian deskripstif dengan data yang digunakan adalah laporan keuangan yang berfokus pada laporan neraca dan laporan laba rugi tahun 2013 - 2016 pada Bank Mandiri. Yaitu penelitian yang mendeskripsikan keadaan berdasarkan data yang berupa angka yang telah dikumpulkan. Analisis data yang digunakan adalah analisis CAMEL yang digunakan untuk menilai tingkat kesehatan keuangan bank berdasarkan permodalan, kualitas aktiva produktif (KAP), manajemen, rentabilitas, dan likuiditas. Sumber data dalam penelitian ini adalah pada laporan keuangan yang dapat diperoleh dari website. Metode pengumpulan data dalam penelitian ini adalah dokumentasi yaitu pengumpulan data dengan cara mengumpulkan data sekunder yang sudah didokumentasikan yang berupa laporan keuangan tahunan yang diperoleh dari website dari bank untuk mendapatkan data laporan keuangan berupa neraca dan laporan rugi laba.
\end{abstract}

Kata kunci: Laporan Keuangan, Rasio CAMEL, Tingkat Kesehatan Bank

\section{PENDAHULUAN}

Perbankan merupakan tulang punggung dalam membangun sistem perekonomian dan keuangan Indonesia karena dapat berfungsi sebagai intermediary institution yaitu lembaga yang mampu menyalurkan kembali dana-dana yang dimiliki oleh unit ekonomi yang surplus kepada unit-unit ekonomi yang membutuhkan bantuan dana atau defisit. Fungsi ini merupakan mata rantai yang penting dalam melakukan bisnis karena berkaitan dengan penyediaan dana sebagai investasi dan modal kerja bagi unit-unit bisnis dalam melaksanakan fungsi produksi. Oleh karena itu agar dapat berjalan dengan lancar maka lembaga perbankan harus berjalan dengan baik pula. Analisis yang dilakukan disini berupa penilaian tingkat kesehatan bank. Kesehatan suatu bank adalah kemampuan suatu bank untuk melakukan kegiatan operasional perbankan secara normal dan mampu memenuhi semua kewajibannya dengan baik dengan cara-cara yang sesuai dengan peraturan perbankan yang berlaku. Salah satu penyebab kesehatan bank menurun dikarenakan terjadinya kredit macet, untuk itu bank harus memiliki syarat penting untuk memitigasi terjadinya kredit bermasalah dikemudian hari.

Penelitian ini merujuk pada penelitian sebelumnya yang dilakukan oleh Ariani (2016) menghasilkan beberapa kesimpulan antara lain: mendapatkan nilai CAMEL tahun 2011 sebesar 84,5, tahun 2012 sebesar 85,6, tahun 2013 sebesar 88,7, dan tahun 2014 sebesar 84,5 dapat di simpulkan bahwa Bank Mandiri Tbk berada pada peringkat komposit 1 (Sangat Baik) atau digolongkan dalam kondisi sehat. 


\section{Perumusan Masalah}

Berdasarkan latar belakang yang telah diuraikan, maka yang menjadi masalah pokok dalam penelitian ini adalah bagaimana tingkat kesehatan bank mandiri cabang dolok masihul yang diukur menggunakan rasio CAMEL yang meliputi penilaian berdasarkan Capital (modal), Assets (aktiva), Management (manajemen), Earning (rentabilitas), dan Liquidity (Likuiditas).

\section{Batasan Masalah}

Untuk memperjelas arah penelitian maka penulis membatasi hal ini dengan menggunakan rasio CAMEL yang meliputi penilaian berdasarkan Capital (modal), Assets (aktiva), Management (manajemen), Earning (rentabilitas), dan Liquidity (Likuiditas) yang berdasarkan pada laporan keuangan di PT Bank Mandiri (Persero) dari tahun 2013-2016.

\section{Tujuan Penelitian}

Sehubungan dengan rumusan masalah tersebut, maka tujuan penelitian ini adalah untuk mengetahui tingkat kesehatan pada PT Bank Mandiri (Persero) Tbk cabang Dolok Masihul dengan melihat dari segi Capital (modal), Assets (aktiva), Management (manajemen), Earning (rentabilitas), dan Liquidity (Likuiditas).

\section{METODE PENELITIAN}

\section{Metode Pengumpulan Data}

Dalam penulisan ilmiah ini, penulis menggunakan data sekunder dalam upaya pengumpulan data dan penulis memperoleh data dari berbagai sumber, diantaranya adalah:

1. Data literatur yang berkaitan dengan penulisan ilmiah ini.

2. Data yang bersumber dari situs resmi Bursa Efek Indonesia (www.idx.co.id) yang bersangkutan dan terdiri dari:

a. Data Kuantitatif

Yaitu data yang dinyatakan dengan angka-angka yang berasal dari laporan keuangan PT. Bank Mandiri (Persero) Tbk.

b. Data Primer

Yaitu data yang diperoleh secara langsung dari sumber aslinya yang berupa wawancara, maupun hasil observasi dari suatu obyek, kejadian atau hasil pengujian (benda).

3. Data Kualitatif

Yaitu data yang tidak dinyatakan dengan angka tetapi berupa keterangan berkaitan dengan ini diantaranya adalah Peraturan Bank Indonesia.

\section{Metode Analisis Data}

Dalam penelitian ini untuk mengolah data dari hasil penelitian ini dengan menggunakan analisis deskriptif dengan mencari nilai rasio yang didapat dengan memperhitungkan masing-masing faktor dan komponen.

\section{HASIL DAN PEMBAHASAN}

\section{Faktor Rentabilitas (Earning)}

1. Return On Assets (ROA) Rasio ini digunakan untuk mengukur kemampuan manajemen bank dalam memperoleh keuntungan (laba bersih sebelum pajak) secara keseluruhan. Semakin besar $R O A$, semakin besar pula tingkat keuntungan yang dicapai bank, sehingga kemampuan suatu bank dalam suatu kondisi bermasalah semakin kecil. Perhitungan $R O A$ pada Bank Mandiri dapat dijelaskan sebagai berikut:

$$
\text { Return On Assets }=\frac{\text { Laba Sebelum Pajak }}{\text { Total Aktiva }} \times 100 \%
$$


Besarnya rasio $R O A$ pada tahun 2013-2016 dapat ditentukan sebagai berikut:

Tabel 1 ROA Bank Mandiri Tbk Tahun 2013 s/d 2016

\begin{tabular}{|l|c|c|c|c|}
\hline \multicolumn{1}{|c|}{ Tahun } & $\mathbf{2 0 1 3}$ & $\mathbf{2 0 1 4}$ & $\mathbf{2 0 1 5}$ & $\mathbf{2 0 1 6}$ \\
\hline Laba Sebelum Pajak & 24.061 .837 & 26.008 .015 & 26.369 .430 & 18.572 .965 \\
\hline Total Aktiva & 648.250 .177 & 757.039 .212 & 807.551 .112 & 918.181 .510 \\
\hline Rasio $R O A$ & $3,71 \%$ & $3,43 \%$ & $3,26 \%$ & $2,02 \%$ \\
\hline
\end{tabular}

Sumber: Data Olahan 2017 ( Dalam Jutaan Rp)

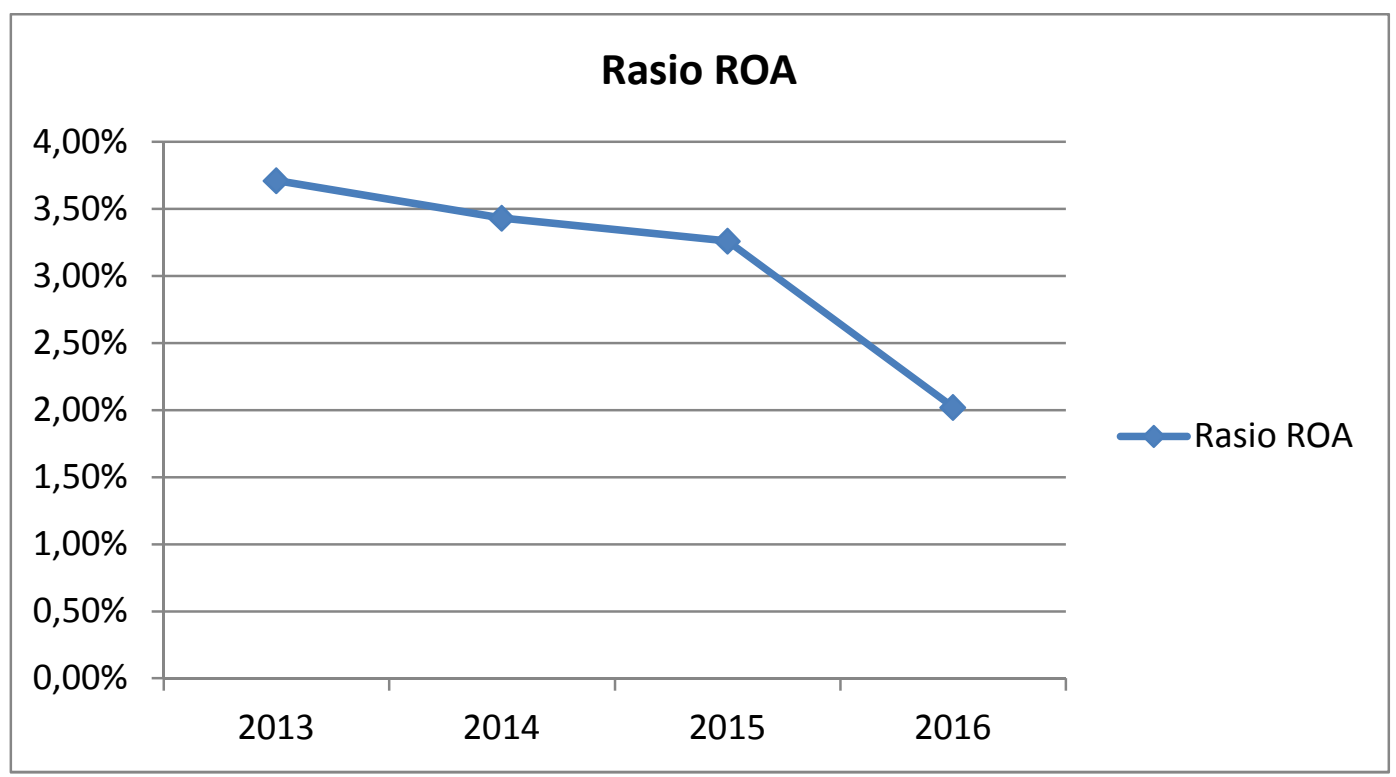

Gambar 2. Rasio ROA Bank Mandiri Periode Tahun 2013-2016

Berdasarkan tabel 4.7 dan grafik 4.4 diatas, hasil perhitungan rasio ROA pada Bank Mandiri Tbk tahun 2013 sebesar 3,71\%,tahun 2014 sebesar 3,43\%, tahun 2015 sebesar 3,26\%, dan tahun 2016 sebesar 2,02\% dikategorikan kurang sehat karena terjadi penurunan setiap tahunnya. Dari hasil perhitungan rasio rasio $R O A$ maka dapat dilakukan perhitungan nilai kredit untuk rasio $R O A$ yaitu:

1. Untuk rasio $0 \%$ atau negatif diberi nilai kredit 0 , dan

2. Untuk setiap kenaikan $0,015 \%$ mulai dari $0 \%$ nilai kredit ditambah 1 dengan maksimum 100 .

Nilai Kredit $=\frac{\text { Rasio }}{0,015}$

Dengan demikian maka besarnya nilai kredit untuk rasio ROA untuk tahun 2013-2016 dapat dihitung sebagai berikut:

1. Tahun 2013

Nilai Kredit $=\frac{3,7 \%}{0,015}=247$ maksimum 100

2. Tahun 2014

Nilai Kredit $=\frac{3,4 \%}{0,015}=227$ maksimum 100

3. Tahun 2015

Nilai Kredit $=\frac{3,2 \%}{0,015}=213$ maksimum 100

4. Tahun 2016

Nilai Kredit $=\frac{2 \%}{0,015}=133$ maksimum 100

Untuk lebih jelasnya hasil perhitungan Nilai Kredit rasio $R O A$ dapat ditentukan melalui tabel berikut ini: 
Tabel 3 Nilai Kredit ROA Bank Mandiri Tbk Tahun 2013 s/d 2016

\begin{tabular}{|l|c|c|c|c|}
\hline \multicolumn{1}{|c|}{ Tahun } & $\mathbf{2 0 1 3}$ & $\mathbf{2 0 1 4}$ & $\mathbf{2 0 1 5}$ & $\mathbf{2 0 1 6}$ \\
\hline Nilai Kredit ROA & 247 & 227 & 213 & 133 \\
\hline Maximum & - & -20 & -14 & -80 \\
\hline Pertumbuhan & - & \multicolumn{5}{|c|}{100} \\
\hline
\end{tabular}

Sumber: Data Olahan (2017)

Berdasarkan tabel 4.8 di atas, nilai kredit untuk rasio ROA untuk tahun 2013 sebesar 247, tahun 2014 sebesar 227, tahun 2015 sebesar 213, dan tahun 2016 sebesar 133. Menunjukkan bahwa nilai kredit rasio $R O A$ mengalami penurunan. Sedangkan menurut ketentuan dari Bank Indonesia nilai maksimum adalah 100, sehingga nilai kredit rasio CAMEL untuk 4 (empat) tahun ditentukan sebesar 100.

Berdasarkan hasil perhitungan nilai kredit rasio $R O A$ lebih besar dari kriteria penilaian tingkat kesehatan bank yang ditetapkan oleh Bank Indonesia sebesar 1,22\% maka rasio yang dicapai dikategorikan dalam kelompok sehat.

\section{BOPO}

Rasio BOPO (Beban Operasional Terhadap Pendapatan Operasional) digunakan untuk mengukur tingkat efisiensi dan kemampuan bank dalam melakukan kegiatan operasinya. Rasio BOPO diperoleh dengan cara membagi biaya operasional dengan pendapatan operasional, ditentukan sebagai berikut:

$$
\mathrm{BOPO}=\frac{\text { Biaya Operasional }}{\text { Pendapatan Operasional }}
$$

Tabel 4 BOPO Bank Mandiri Tbk Tahun 2013 s/d 2016

\begin{tabular}{|l|c|c|c|c|}
\hline \multicolumn{1}{|c|}{ BOPO } & $\mathbf{2 0 1 3}$ & $\mathbf{2 0 1 4}$ & $\mathbf{2 0 1 5}$ & $\mathbf{2 0 1 6}$ \\
\hline Beban Operasional & 22.533 .779 & 25.374 .351 & 28.754 .543 & 31.268 .198 \\
\hline Pendapatan Operasional & 23.551 .711 & 25.978 .106 & 26.338 .972 & 18.612 .727 \\
\hline Rasio BOPO & $95,68 \%$ & $97,68 \%$ & $109,1 \%$ & $167,9 \%$ \\
\hline
\end{tabular}

Sumber: Data Olahan 2017 (Dalam Jutaan Rp)

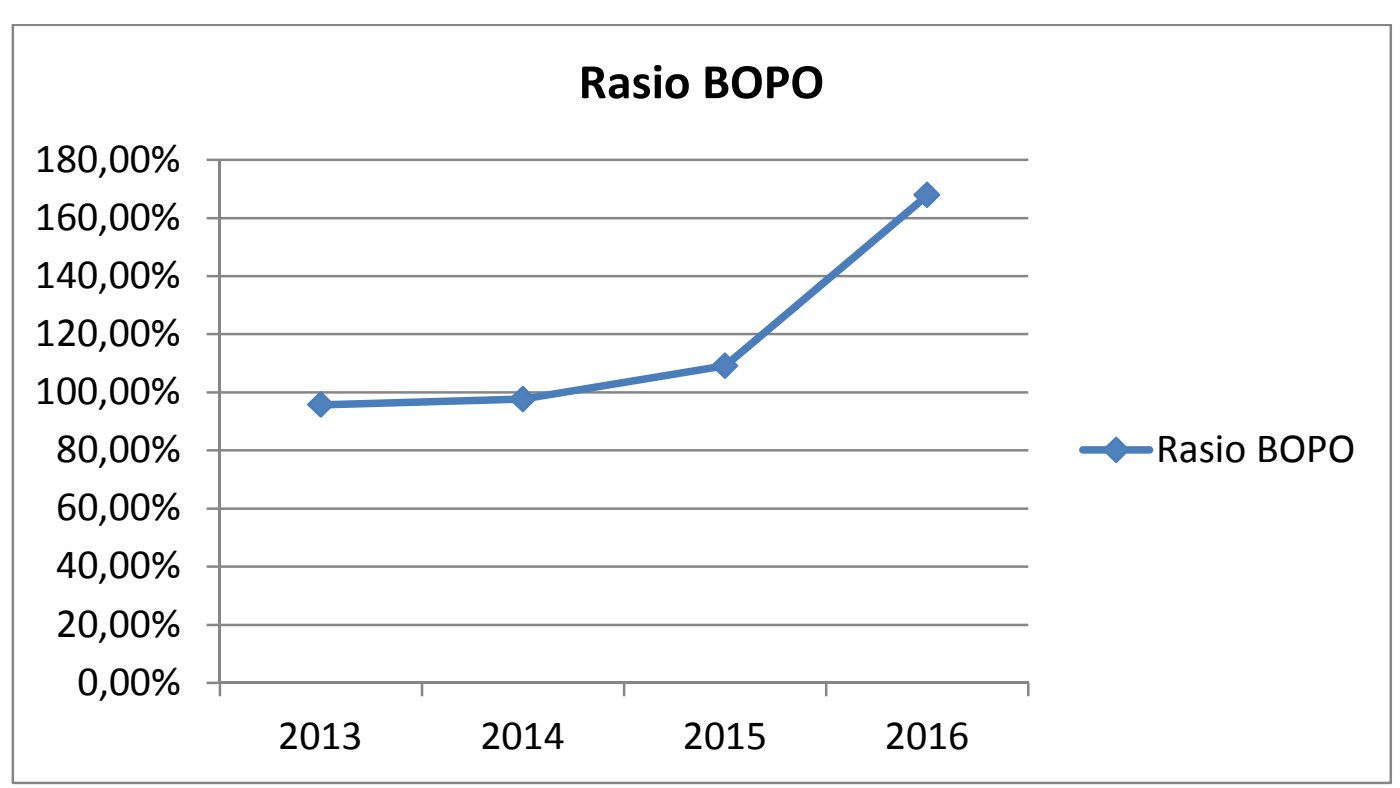

Gambar 1. Rasio BOPO Bank Mandiri Periode Tahun 2013-2016 
Berdasarkan tabel 4.9 dan grafik 4.5 di atas hasil perhitungan Rasio Biaya BOPO pada Bank Mandiri tahun 2013 sebesar 95,68\%, tahun 2014 sebesar 97,68\%, tahun 2015 sebesar 109,1\%, dan tahun 2016 sebesar 167,9\% > 97\% dapat dikategorikan dalam kelompok tidak sehat karena setiap tahunnya persentase rasio terus meningkat. Sesuai ketetapan Bank Indonesia yaitu semakin besar rasio BOPO maka semakin besar Beban Operasional Terhadap Pendapatan Operasional bank dalam melakukan kegiatan operasionalnya.

Dari hasil perhitungan rasio BOPO maka dapat dilakukan perhitungan nilai kredit untuk rasio BOPO menurut ketentuan Bank Indonesia yaitu:

1. Untuk rasio $100 \%$ atau lebih diberi nilai kredit 0 , dan

2. Untuk setiap penurunan $0,08 \%$ mulai dari $100 \%$ nilai kredit ditambah 1 dengan maksimum 100 sesuai ketentuan Bank Indonesia.

$$
\text { Nilai Kredit }=\frac{100-B O P O}{0,08}
$$

Berdasarkan rumus tersebut diatas, maka hasil perhitungan Nilai Kredit BOPO dapat diuraikan sebagai berikut:

1. Tahun 2013

$$
\text { Nilai Kredit }=\frac{100-95,68 \%}{0,08}=118,3
$$

2. Tahun 2014

$$
\text { Nilai Kredit }=\frac{100-97,68 \%}{0,08}=-112,1
$$

3. Tahun 2015

$$
\text { Nilai Kredit }=\frac{100-109,1 \%}{0,08}=-126,3
$$

4. Tahun 2016

$$
\text { Nilai Kredit }=\frac{100-167,9 \%}{0,08}=-199,8
$$

Untuk lebih jelasnya hasil perhitungan Nilai Kredit rasio BOPO dapat ditentukan melalui tabel berikut ini:

Tabel 5 Nilai Kredit BOPO Bank Mandiri Tbk Tahun 2013 s/d 2016

\begin{tabular}{|l|c|c|c|c|}
\hline \multicolumn{1}{|c|}{ Tahun } & $\mathbf{2 0 1 3}$ & $\mathbf{2 0 1 4}$ & $\mathbf{2 0 1 5}$ & $\mathbf{2 0 1 6}$ \\
\hline Nilai Kredit BOPO & 118,3 & $-112,1$ & $-126,3$ & $-199,8$ \\
\hline Maximum & \multicolumn{5}{|c|}{100} \\
\hline Pertumbuhan & - & $-230,4$ & 14,2 & 73,5 \\
\hline
\end{tabular}

Sumber: Data Olahan (2017)

Berdasarkan tabel 4.10 di atas, nilai kredit untuk rasio BOPO untuk tahun 2013 sebesar 118,3, tahun 2014 sebesar -112,1, tahun 2015 sebesar 14,2, dan tahun 2016 sebesar 73,5. Menunjukkan bahwa nilai kredit rasio BOPO diatas $100 \%$ hanya pada tahun 2013 saja sedangkan menurut ketentuan dari Bank Indonesia nilai maksimum 100. Rasio BOPO pada tahun 2014, 2015 dan 2016 nilai kredit BOPO > 97\% tergolong tidak sehat. Artinya bank tidak sehat dalam mengendalikan biaya operasional terhadap pendapatan operasionalnya.

\section{Faktor Likuiditas (Liquidity)}

Berdasarkan ketentuan yang sudah dikeluarkan oleh Bank Indonesia, komponen likuiditas bank diukur berdasarkan Loan to Deposite Ratio (LDR) yang menyatakan seberapa jauh kemampuan bank dalam membayar kembali penarikan dana yang dilakukan deposan dengan mengandalkan kredit yang diberikan sebagai sumber likuiditasnya. Semakin tinggi rasio tersebut memberikan indikasi semakin rendahnya kemampuan likuiditas bank yang bersangkutan.

$$
\text { Loan To Deposite Ratio }=\frac{\text { Jumlah Kredit Yang Diberikan }}{\text { Total Dana Pihak Ketiga }} \times 100 \%
$$

Besarnya rasio LDR pada Bank Mandiri Tbk dapat ditentukan sebagai berikut: 
Tabel 6 LDR Bank Mandiri Tbk Pada Tahun 2013 s/d 2016

\begin{tabular}{|l|c|c|c|c|}
\hline \multicolumn{1}{|c|}{ Tahun } & $\mathbf{2 0 1 3}$ & $\mathbf{2 0 1 4}$ & $\mathbf{2 0 1 5}$ & $\mathbf{2 0 1 6}$ \\
\hline $\begin{array}{l}\text { Jumlah Kredit } \\
\text { Yang Diberikan }\end{array}$ & 450.634 .798 & 505.394 .870 & 564.393 .595 & 616.706 .193 \\
\hline $\begin{array}{l}\text { Dana Pihak } \\
\text { Ketiga }\end{array}$ & 508.996 .256 & 583.448 .911 & 613.160 .929 & 687.949 .844 \\
\hline Rasio $L D R$ & $88,53 \%$ & $86,62 \%$ & $92,04 \%$ & $89,64 \%$ \\
\hline
\end{tabular}

Sumber: Data Olahan 2017 (Dalam Jutaan Rp)

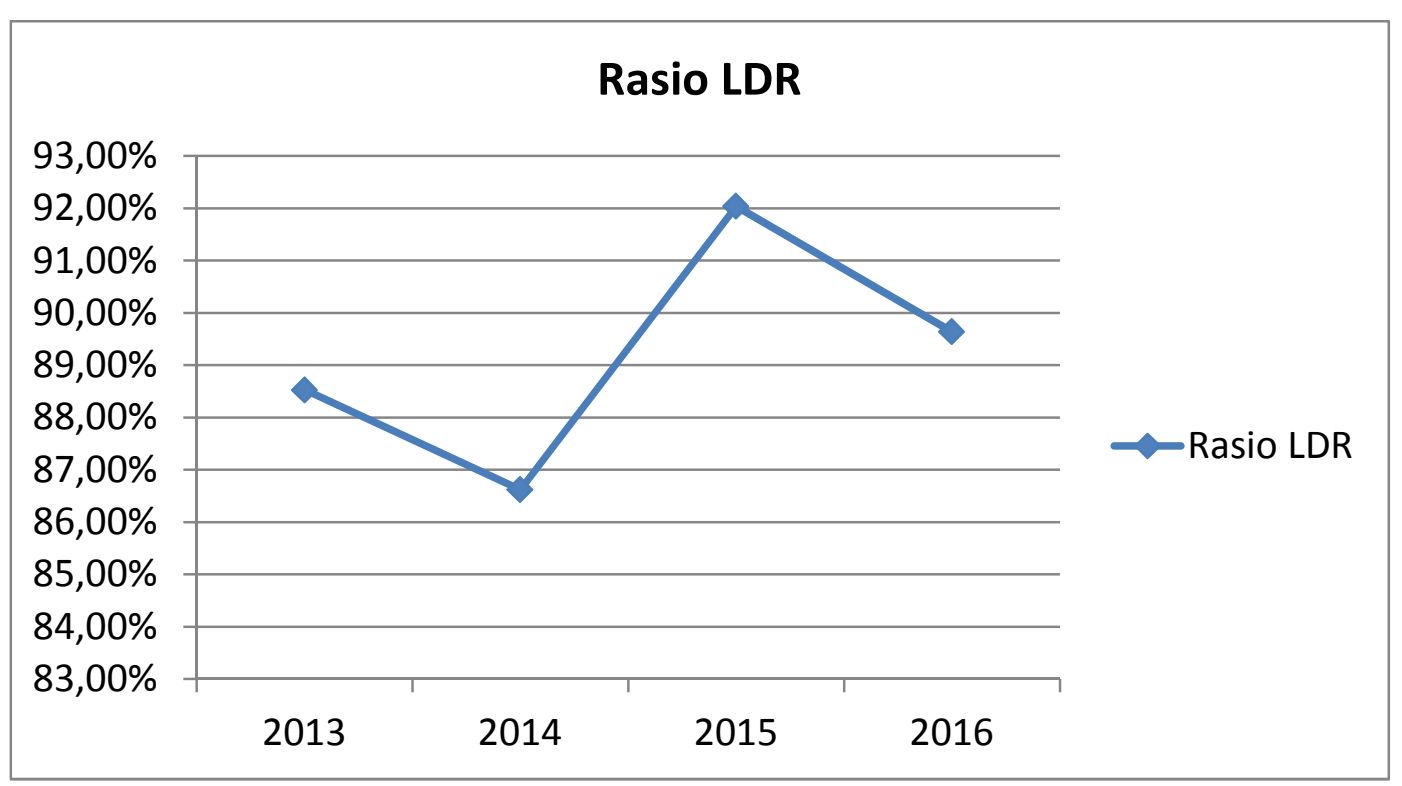

Gambar 2 Rasio LDR Bank Mandiri Periode Tahun 2013 - 2016

Berdasarkan tabel 4.11 dan gambar 4.6 di atas, hasil perhitungan rasio LDR Bank Mandiri Tbk pada tahun 2013 sebesar 88,53\%, dan turun tahun 2014 sebesar 86,62\%, tahun 2015 meningkat cukup signifikan sebesar 92,04\% dan pada tahun 2016 turun kembali sebesar $89,64 \%$, namun masih tergolong dalam batasan aman menurut standar Bank Indonesia yaitu $\leq$ 100\%. Jumlah Dana Pihak Ketiga (DPK) yang berhasil dihimpun dari masyarakat oleh Bank Mandiri sebanding dengan jumlah kredit yang diberikan.

Untuk dapat menentukan nilai CAMEL yang diperoleh Bank Mandiri untuk rasio LDR, terlebih dahulu harus diketahui nilai kredit yang dihasilkan dari rasio LDR ini. Dari nilai kredit yang diperoleh dapat dilihat kondisi suatu bank secara umum bila telah digabungkan dengan komponen yang lainnya dalam rasio CAMEL. Bobot nilai kredit untuk rasio LDR ini diperoleh dari pengurangan nilai kredit maksimal dari rasio LDR berdasarkan ketentuan Bank Indonesia dengan nilai rasio LDR yang telah diperoleh. Bobot nilai kredit rasio LDR untuk dapat dikategorikan sebagai bank yang sehat berdasarkan ketentuan Bank Indonesia adalah sebesar 100.

Nilai Kredit $=1+\frac{(115-\text { Rasio })}{1,00} \times 4$

Berdasarkan rumus tersebut diatas, maka hasil perhitungan nilai kredit LDR dapat diuraikan sebagai berikut:

1. Tahun 2013

Nilai Kredit $=1+\frac{(115-88,53)}{1,00} \times 4=109,88$

2. Tahun 2014

Nilai Kredit $=1+\frac{(115-86,62)}{1,00} \times 4=117,52$

3. Tahun 2015 


$$
\text { Nilai Kredit }=1+\frac{(115-92,04)}{1,00} \times 4=95,84
$$

4. Tahun 2016

$$
\text { Nilai Kredit }=1+\frac{(115-89,64)}{1,00} \times 4=105,44
$$

Dan untuk tabel nilai kredit LDR pada PT. Bank Mandiri tahun 2013 sampai 2016 dapat dilihat pada tabel 7 berikut ini:

Tabel 7 Nilai Kredit LDR Bank Mandiri Tbk Tahun 2013 s/d 2016

\begin{tabular}{|l|c|c|c|c|}
\hline \multicolumn{1}{|c|}{ Tahun } & $\mathbf{2 0 1 3}$ & $\mathbf{2 0 1 4}$ & $\mathbf{2 0 1 5}$ & $\mathbf{2 0 1 6}$ \\
\hline Nilai Kredit LDR & 109,88 & 117,52 & 95,84 & 105,44 \\
\hline Maximum & - & 7,64 & $-21,68$ & $-9,6$ \\
\hline Pertumbuhan & - & 100 \\
\hline
\end{tabular}

Sumber: Data Olahan (2017)

Berdasarkan tabel 4.12 di atas, nilai kredit untuk rasio LDR untuk tahun 2013 sebesar 109,88, tahun 2014 sebesar 117,52, tahun 2015 sebesar -21,68, dan pada tahun 2016 sebesar 9,6. Ini menunjukkan bahwa nilai kredit rasio CAR mengalami kenaikan dan penurunan. Sedangkan menurut ketentuan Bank Indonesia nilai maksimum 100, sehingga nilai kredit rasio CAMEL untuk 4 (empat) tahun ditentukan sebesar 100.

\section{Pembahasan}

Untuk menilai suatu kesehatan bank dapat dilihat dari berbagai segi. Penilaian ini bertujuan untuk menentukan apakah bank tersebut dalam kondisi yang sehat, cukup sehat, kurang sehat atau tidak sehat. Bagi bank yang sehat agar tetap mempertahankan kesehatannya, sedangkan bank yang sakit untuk segera mengobati penyakitnya. Standar untuk melakukan penilaian kesehatan bank telah ditentukan oleh pemerintah melalui Bank Indonesia, diantaranya yaitu kepada bank-bank diharuskan membuat laporan yang bersifat rutin ataupun secara berjangka berkala mengenai seluruh aktivitasnya dalam suatu periode tertentu.

Bank Indonesia sebagai pengawas dan pembina perbankan dapat saja menyarankan untuk melakukan berbagai perbaikan. Perbaikan-perbaikan yang akan dilakukan meliputi perubahan manajemen, melakukan penggabungan seperti merger, konsolidasi, akuisisi dan dilikuidasi (dibubarkan) keberadaannya jika sudah dalam kondisi yang sangat tidak sehat bank tersebut. Pertimbangan untuk hal ini sangat tergantung dari kondisi yang dialami bank yang bersangkutan. Jika kondisi bank sudah sedemikian tidak sehat, namun masih memiliki beberapa potensi, maka sebaiknya dicarikan jalan keluarnya dengan cara penggabungan usaha dengan banknya. Sedangkan langkah likuidasi merupakan karakter akhir dalam rangka menyelamatkan uang masyarakat.

Aspek-aspek penilaian dalam menentukan kondisi suatu bank biasanya menggunakan berbagai alat ukur. Salah satu alat ukur yang utama digunakan untuk menentukan kondisi suatu bank dikenal dengan nama analisis CAMEL (Capital, Assets, Management, Earning, dan Liquidity). Hasil dari masing-masing aspek ini kemudian akan menghasilkan kondisi baru suatu bank.

Penentuan bobot didasarkan kepada masing-masing aspek diatas diberikan nilai, kemudian dijumlahkan secara keseluruhan dari komponen. Secara garis besar hasil penilaian ini ditetapkan ke dalam 4 golongan predikat kesehatan bank.

Hasil penilaian terhadap analisis $C A M E L$, kemudian dituangkan dalam bentuk angka yang diberikan bobot sesuai ketentuan yang telah ditetapkan. Bobot nilai ini diberikan sebagai 
nilai kredit. Dari bobot nilai ini dapat dipastikan kondisi suatu bank. Maka akan dilakukan perhitungan bobot dengan menggunakan metode CAMEL untuk tahun 2013 - 2016 yang dapat dilihat melalui tabel berikut ini:

Tabel 8 Hasil Evaluasi CAMEL Bank Mandiri Tbk Tahun 2013 s/d 2016

\begin{tabular}{|c|c|c|c|c|c|c|}
\hline Tahun & $\begin{array}{l}\text { Faktor } \\
\text { Penilaian }\end{array}$ & $\begin{array}{c}\text { Indikator } \\
\text { Kerja }\end{array}$ & $\begin{array}{c}\text { Nilai } \\
\text { Rasio } \\
\text { (\%) }\end{array}$ & $\begin{array}{l}\text { Nilai } \\
\text { Kredit }\end{array}$ & $\begin{array}{c}\text { Bobot } \\
(\%)\end{array}$ & $\begin{array}{c}\text { Nilai } \\
\text { CAMEL }\end{array}$ \\
\hline \multirow[t]{6}{*}{2013} & Permodalan & CAR & 15 & 100 & 25 & 25 \\
\hline & Kualitas Aktiva & $K A P$ & 3,4 & 100 & 30 & 30 \\
\hline & $\begin{array}{l}\text { Produktif } \\
\text { Manaiemen }\end{array}$ & $N P M$ & 80 & 80 & 25 & 32 \\
\hline & Earning & 1. $R O A$ & 3,7 & 100 & 5 & 5 \\
\hline & & 2. $B O P O$ & 95,6 & 100 & 5 & 5 \\
\hline & Likuiditas & $L D R$ & 88,5 & 100 & 10 & 10 \\
\hline \multicolumn{6}{|c|}{ Jumlah Nilai $C A M E L$} & 78,2 \\
\hline \multirow[t]{6}{*}{2014} & Permodalan & $C A R$ & 16,6 & 100 & 25 & 25 \\
\hline & $\begin{array}{l}\text { Kualitas Aktiva } \\
\text { Produktif }\end{array}$ & $K A P$ & 4,2 & 100 & 30 & 30 \\
\hline & Manajemen & $N P M$ & 79,5 & 79,5 & 25 & 3,1 \\
\hline & Earning & 1. $R O A$ & 3,4 & 100 & 5 & 5 \\
\hline & & 2. $B O P O$ & 97,6 & 100 & 5 & 5 \\
\hline & Likuiditas & $L D R$ & 86,6 & 100 & 10 & 10 \\
\hline \multicolumn{6}{|c|}{ Jumlah Nilai $C A M E L$} & 78,1 \\
\hline \multirow[t]{6}{*}{2015} & Permodalan & $C A R$ & 18,6 & 100 & 25 & 25 \\
\hline & $\begin{array}{l}\text { Kualitas Aktiva } \\
\text { Produktif }\end{array}$ & $K A P$ & 4,5 & 100 & 30 & 30 \\
\hline & Manajemen & $N P M$ & 80,3 & 80,3 & 25 & 3,2 \\
\hline & Earning & 1. $R O A$ & 3,2 & 100 & 5 & 5 \\
\hline & & 2. $B O P O$ & 109 & 100 & 5 & 5 \\
\hline & Likuiditas & $L D R$ & 92 & 100 & 10 & 10 \\
\hline \multicolumn{6}{|c|}{ Jumlah Nilai $C A M E L$} & 78,2 \\
\hline \multirow[t]{7}{*}{2016} & Permodalan & $C A R$ & 21,3 & 100 & 25 & 25 \\
\hline & Kualitas Aktiva & $K A P$ & 5 & 100 & 30 & 30 \\
\hline & Produktif & & & 100 & & \\
\hline & Manajemen & $N P M$ & 78,7 & 78,7 & 25 & 3,1 \\
\hline & Earning & 1. $R O A$ & 2 & 100 & 5 & 5 \\
\hline & & 2. $B O P O$ & 168 & 100 & 5 & 5 \\
\hline & Likuiditas & $L D R$ & 89,6 & 100 & 10 & 10 \\
\hline \multicolumn{6}{|c|}{ Jumlah Nilai $C A M E L$} & 78,1 \\
\hline
\end{tabular}

Berdasarkan tabel 8 yakni hasil perhitungan nilai rasio CAMEL, maka dapat disajikan hasil penilaian kesehatan keuangan dengan rasio CAMEL khususnya dalam tahun 2013 s/d tahun 2016, yang dapat dilihat melalui tabel berikut ini:

Tabel 94 Golongan Predikat Tingkat Kesehatan Bank

\begin{tabular}{|c|c|}
\hline Nilai $\boldsymbol{C A M E L}$ & $\begin{array}{c}\text { Tingkat Kesehatan } \\
\text { Keuangan }\end{array}$ \\
\hline $81-100$ & Sehat \\
\hline $66-<81$ & Cukup Sehat \\
\hline
\end{tabular}




\begin{tabular}{|c|c|}
\hline $51-<66$ & Kurang Sehat \\
\hline $0-<51$ & Tidak Sehat \\
\hline
\end{tabular}

Tabel 10: Hasil Penilaian Tingkat Kesehatan Bank Mandiri Tbk Tahun 2013 s/d 2016

\begin{tabular}{|c|c|c|}
\hline Tahun & Nilai CAMEL & $\begin{array}{c}\text { Tingkat Kesehatan } \\
\text { Keuangan }\end{array}$ \\
\hline 2013 & 78,2 & Cukup Sehat \\
\hline 2014 & 78,1 & Cukup Sehat \\
\hline 2015 & 78,2 & Cukup Sehat \\
\hline 2016 & 78,1 & Cukup Sehat \\
\hline
\end{tabular}

Hasil penelitian menunjukkan bahwa Analisis CAMEL pada Bank Mandiri Tbk, untuk tahun 2013-2016 kondisi tingkat kesehatan Bank Mandiri dinyatakan cukup sehat. Mencerminkan bahwa bank mampu mengatasi pengaruh negatif kondisi perekonomian dan industri keuangan namun bank masih memiliki kelemahan-kelemahan minoritas yang dapat segera diatasi oleh tindakan rutin. Analisis terhadap tingkat kesehatan bank bertujuan untuk mengevaluasi kinerja bank dalam menerapkan prinsip kehati-hatian dan kepatuhan terhadap ketentuan yang berlaku. Selain itu, hasil penilaian tingkat kesehatan bank diharapkan dapat membantu calon investor dalam membuat keputusan sebelum melakukan investasi pada bank.

\section{Kesimpulan}

Setelah melakukan pembahasan pada bab-bab sebelumnya dengan menganalisis tingkat kesehatan pada Bank Mandiri Tbk, maka penulis dapat memberikan kesimpulan sebagai berikut:

1. Berdasarkan hasil analisis dan pembahasan mengenai tingkat kesehatan Bank menggunakan metode CAMEL pada Bank Mandiri Tbk, mendapatkan nilai $C A M E L$ tahun 2013 sebesar 78,2, tahun 2014 sebesar 78,1, tahun 2015 sebesar 78,2, dan tahun 2016 sebesar 78,1. Maka dapat simpulkan bahwa Bank Mandiri Tbk berada pada peringkat komposit 2 (Cukup Baik) atau digolongkan dalam kondisi cukup sehat.

2. Pada faktor manajemen, Net Profit Margin tergolong tinggi, pada tahun 2016 mencapai $78,71 \%$. Ketentuan dari Bank Indonesia persentase rasio $66 \% \leq \mathrm{NPM}<81 \%$ tergolong cukup sehat, dan tidak berada pada posisi sehat. Artinya pendapatan operasional bank sedang mengalami penurunan terutama yang berasal dari kegiatan pemberian kredit yang dalam praktiknya memiliki berbagai risiko, seperti risiko kredit, bunga, kurs valas, dan lain-lain.

3. Setelah diteliti dan dipelajari, tingkat kesehatan Bank Mandiri periode 2013 s/d 2016 mengalami penurunan kualitas. Seperti pada rasio Net Profit Margin yaitu pada tahun 2013 sebesar 79,96\%, tahun 2014 sebesar 79,51\%, tahun 2015 sebesar 80,31\%, dan tahun 2016 sebesar 78,71\%. Data tersebut menunjukkan bahwa alokasi dana dari tahun ke tahun tidak tetap. Net Profit Margin pada tahun 2015 tergolong tinggi.

4. Hasil perhitungan rasio ROA pada Bank Mandiri Tbk tahun 2013 sebesar 3,71\%,tahun 2014 sebesar 3,43\%, tahun 2015 sebesar 3,26\%, dan tahun 2016 sebesar 2,02\% dikategorikan kurang sehat karena terjadi penurunan setiap tahunnya.

5.Pada rasio LDR Jumlah Dana Pihak Ketiga (DPK) yang berhasil dihimpun dari masyarakat oleh Bank Mandiri menunjukkan hasil yang naik dan turun, dimana pada tahun 2013 sebesar 88,53\%, dan turun tahun 2014 sebesar 86,62\%, tahun 2015 meningkat cukup signifikan sebesar 92,04\% dan pada tahun 2016 turun kembali sebesar $89,64 \%$, namun masih tergolong dalam batasan aman menurut standar Bank Indonesia yaitu $\leq 100 \%$. 


\section{REFERENCES}

Batubara, A., \& Hidayat, R. (2016). Pengaruh Penetapan Harga dan Promosi terhadap Tingkat Penjualan Tiket pada PSA Mihin Lanka Airlines. Jurnal Ilman, 4(1), 33-46.

Cece. (2003). Analisis Hubungan Perencanaan Strategi Aliansi PDAM Tirtanadi-PT. Telekominikasi Divre I Terhadap Peningkatan Kualitas Pelayanan Pelanggan PDAM Tirtanadi... Universitas Sumatera Utara.

Dinamika, S. G. (2018). Gemstone Fever Hits Jakarta: A Lexical Meaning Analysis.

Dinamika, S. G., \& Sari, W. V. (2015). Applied Error Analysis of Comparative Degree Sentence Construction of Students in STIM Sukma Medan. Asian EFL Journal, 5, 112-119.

Dinamika, Soraya Grabiella (2014) THE EFFECT OF USING COLLABORATIVE STRATEGIC READING ON STUDENTS' ACHIEVEMENT IN READING NARRATIVE TEXT. Undergraduate thesis, UNIMED

Fathimah, V. (2017). Pengaruh Perkembangan Jumlah Tabungan, Deposito dan Bagi Hasil terhadap Jumlah Pembiayaan yang Diberikan oleh Perbankan Syariah di Sumatera Utara. Jurnal Ilman, $5(1), 41-52$.

Ikatan Akuntan Indonesia. (2015). Tingkat Kesehatan Bank. Jakarta: Pustaka Indonesia.

Institut Bankir Indonesia. (1999). Kamus Perbankan. Bandung: Erlangga.

Kasmir. (2013). Manajemen Perbankan. (2nd ed). Jakarta: Inti Perdana Perkasa.

Kasmir. (2014). Manajemen Keuangan dan Perbankan. (3rd ed). Jakarta: Inti Perdana Perkasa.

Lubis, D. I. D., \& Hidayat, R. (2017). Pengaruh Citra Merek dan Harga terhadap Keputusan Pembelian pada Sekolah Tinggi Ilmu Manajemen Sukma Medan. Jurnal Ilman, 5(1), 15-24.

Mirdhani dan Budiyanto. (2014). Kesehatan Bank Umum di Indonesia. Jakarta: Sumber Ilmu. Munawir. (2013). Ilmu Ekonomi Perbankan. Bandung: Paramadya Gemilang.

Myer. (2014). Teori Penerapan Ilmu Ekonomi Pada Perbankan Di Indonesia. Jakarta: Graha Ilmu.

Nasution, W. A. (2009). Pengaruh kepuasan kerja karyawan terhadap intensi turnover pada call center Telkomsel di Medan. Jurnal Mandiri, 4(1), 1-11.

Nasution, W. A. (2013). Pengaruh kompensasi dan lingkungan kerja terhadap kepuasan kerja karyawan pada PT. Karya Deli Stelindo Medan. Jurnal Manajemen Bisnis STIE IBBI, 20(2), 177.

Nasutiona, L. K., Fahrurb, M., Christine, Imaduddind, \& Wardayani. (2017). The Calculation of Cost of Goods Sold "Gayo Arabica Coffee from Takengon" with Variable Costing Method. Journal Online Jaringan COT POLIPD (JOJAPS), 10, 82-87.

Ningratri, Y. A. (2017). Analisis Pengaruh Strategi Bauran Pemasaran Jasa (3P) terhadap Keputusan Mahasiswa Memilih STIM Sukma Medan. Riset \& Ejurnal Manajemen Informatika, 3(1), 5056.

Nurlinda, \& Wardayani. (2014). Pengaruh Partisipasi Penyusunan Anggaran Dan Penggunaan Instrumen Manajemen Terhadap Kinerja Pengelolaan Dana Bantuan Global Fund Komponen Aids Pada Kementerian Kesehatan Ri. Jurnal Ilman, 1(1), 23-35.

Prana, R. R. (2016). Analisis Faktor-faktor yang Mempengaruhi Pendapatan Asli Daerah (PAD) Kota Tebing Tinggi. Jurnal Ilman, 4(1), 74-86.

Raidani, Pertiwi, L. S., Wulandari, D. Y., \& Zuhri. (2016). Tobit and Interval Censored Regression Model. Global Journal of Pure and Applied Mathematics, 12(1), 981-994. 
Sabdillah, R., Hidayat, R., Lubis, D. S. W., \& Wardayani. (2017). Influence of Celebrity Endorser Raisa Andriana in Advertisement on Magnum Ice Cream Brand Image on the Transmart Costumers. Journal Online Jaringan Pengajian Seni Bina (JOJAPS), 10, 112-115.

Safriandi, F., Pertiwi, L. S., Fitriani, A., \& Zuhri. (2016). Truncated Regression Model and Nonparametric Estimation for Gifted and Talented Education Program. Global Journal of Pure and Applied Mathematics, 12(1), 995-1002.

Sinaga, S., Pertiwi, L. S., Ardian, T., \& Zuhri. (2016). Inventory Simulation Optimization Under Non Stationary Demand. International Journal of Applied Engineering Research, 11(1), 524-529.

Sinuhaji, E. (2010). PENERAPAN LAYANAN UNGGUL DALAM PEMASARAN PRODUK BANK. Jurnal Mediasi, 2(1).

Sinuhaji, E. (2013). PENGARUH BUDAYA ORGANISASI TERHADAP KEPUASAN KERJA KARYAWAN PADA JASA PERHOTELAN (Studi Kasus di Garuda Plaza Hotel Medan). Bisnis Administrasi, 2(1), 2537.

Sinuhaji, E. (2014). Pengaruh Kepribadian, Kemampuan Kerja dan Motivasi Kerja terhadap Kinerja SDM Outsourcing pada PT. Catur Karya Sentosa Medan. Jurnal Ilman, 1(1), 11-22.

Sukendro, H. A. (2012). Pengaruh Citra Merek dan Kualitas Pelayanan terhadap Kepuasan Jama'ah pada Kelompok Bimbingan Ibadah Haji (KBIH) Indosat Medan. Universitas Terbuka.

Wahyuni, D. S., \& Wardayani. (2016). Analisis Return on Asset, Current Ratio dan Debt Ratio dalam Menilai Kinerja Keuangan pada PT . Pelabuhan Indonesia I (Persero) cabang Belawan. Jurnal Ilman, 4(1), 59-73.

Widjanarko, B. (2015). PENGARUH PEMERIAN KOMPENSASI DAN KOMUNIKASI TERHADAP SEMANGAT KERJA KARYAWAN PADA BUMI KARYA TAMA INSURANCE CABANG MEDAN. Jurnal Research Sains, 1(2), 130-152.

Winata, E. (2016). Pengaruh Kepuasan Kerja dan Kompensasi terhadap Kinerja Karyawan pada Hotel Inna Dharma Deli Medan. Jurnal Ilman, 4(1), 1-17.

Winata, E. (2016). PENGARUH KOMPENSASI DAN KOMUNIKASI TERHADAP SEMANGAT KERJA KARYAWAN PADA PT. FIF CABANG MEDAN. Jurnal Dunia Ilmu, 2(1), 17-31.

Winata, E. (2017). PENGARUH BAURAN PEMASARAN JASA TERHADAP LOYALITAS KONSUMEN PADA GRAND SERELA HOTEL \& CONVENTION MEDAN. Jurnal Mutiara Manajemen, 1(1), 109-121. 